\title{
Signaling by Insulin-like Growth Factors in Paralyzed Skeletal Muscle: Rapid Induction of IGF1 Expression in Muscle Fibers and Prevention of Interstitial Cell Proliferation by IGF-BP5 and IGF-BP4
}

\author{
Pico Caroni and Corinna Schneider \\ Friedrich Miescher Institute, $\mathrm{CH}-4002$ Basel, Switzerland
}

In the absence of muscle activity, muscle fibers, muscle interstitial cells, and intramuscular nerves display characteristic reactions presumably aimed at restoring a functioning neuromuscular system and avoiding degenerative events. In partially denervated muscle these include proliferation of interstitial cells, followed by nerve sprouting. The same reactions can be induced in intact muscle by elevation of intramuscular insulin-like growth factor (IGF) levels. To determine whether IGFs may participate in the initiation of restorative reactions in inactivated muscle we analyzed the expression of IGF1 and IGF2 mRNA in botulinum toxin-paralyzed and in denervated rat skeletal muscle, and interfered with the activity of IGFs by locally applying the IGF-binding proteins IGF-BP5 and IGF-BP4. To obtain a resolution of the in situ hybridization signals at the cellular level, a nonradioactive method based on digoxigenin-labeled probes was applied. We found that muscle fiber IGF1 mRNA increased rapidly and transiently in inactivated muscle. The time course of this response was similar to that reported for ACh receptor subunits and myogenins. A similar behavior was observed for the corresponding IGF1 protein. The IGF1 response coincided with the transient muscle interstitial cell proliferation reaction. Local application of recombinant IGF-BP5 or IGFBP4, which are endogenous and specific extracellular ligands of IGFs, prevented the stimulation of interstitial cell proliferation in paralyzed muscle. Our data demonstrate the elevated production of the growth factor IGF1 among early reactions in electrically inactive skeletal muscle fibers and indicate that muscle IGFs are required for the induction of intramuscular interstitial cell proliferation. These findings support the hypothesis that in the neuromuscular system IGF 1 plays an important role in initiating cellular reactions in the vicinity of inactive muscle fibers.

IKey words: sprouting, regeneration, neuromuscular junction, insulin-like growth factor, target-derived factor, activitydependent regulation, diffusible activity]

\footnotetext{
Received May 6, 1993; revised Sept. 22, 1993; accepted Dec. 9, 1993.

We are grateful to J. Zapf (Univ. Zurich; recombinant human IGF-BP5 and IGF-BP4), J. A. Fischer (Univ. Zurich; recombinant human IGF1), V. Witzemann (Max Planck Institute, Heidelberg, Germany; purified botulinum toxin A), and G. Roemmele, K. Mueller, and C. Heussler (Ciba-Geigy Corp., Basel, Switzerland; antiserum to recombinant human IGFI) for gifts of reagents; to M. Schmid (CibaGeigy Corp., Basel, Switzerland) for advice on in situ hybridization protocols; and to S. Rotzler (Dept. of Physiology, Univ. of Basel) for help with the denervation experiments. We are especially grateful to D. Monard, K. Burgin, L. Aigner, S. Arber, and $F$. Widmer for critically reading the manuscript.

Correspondence should be addressed to Pico Caroni, Friedrich Miescher Institute, P.O. Box 2543, CH-4002 Basel, Switzerland.

Copyright (C) 1994 Society for Neuroscience $0270-6474 / 94 / 143378-11 \$ 05.00 / 0$
}

The transmission of information from presynaptic nerve to postsynaptic target is essential to a functioning nervous system. The prolonged absence of postsynaptic activation initiates cellular reactions to restore functional synaptic transmission (Purves and Lichtmann, 1985). Prominent among the restorative reactions is the extension of processes from intact nerves in the vicinity of the inactive target, that is, the sprouting reaction (Brown et al., 1981; Brown, 1984; Purves and Lichtmann, 1985). Reactive sprouting is a widespread phenomenon in the nervous system, and it is initiated by locally acting factors, possibly including diffusible substances from inactive targets (Brown et al., 1980; Kuffler, 1989). The sprouting stimulus appears to act with little selectivity, and the distance between the responding nerves and the inactive target is probably a main factor in determining which nerves will sprout (Brown et al., 1980; Slack and Pockett, 1981). Inappropriate connections may subsequently be prevented from forming by more specific mechanisms at the pathfinding, synapse formation, and maintenance stages (Purves and Lichtmann, 1985; Sanes and Couvault, 1985; Sanes, 1989). The sprouting reaction subsides and excess processes are retracted when functioning connections are reestablished.

Sprouting has been studied most extensively at the neuromuscular junction (nmj), the large peripheral synapse between motoneuron and skeletal muscle cell (Brown et al., 1981; Brown, 1984; Salpeter, 1987). Muscle fiber reactions to inactivation are complex and include elevated expression of $\mathrm{ACh}$ receptor subunits (Goldman et al., 1988; Fontaine and Changeux, 1989; Tsay and Schmid, 1990; Witzemann et al., 1991), of a $43 \mathrm{kDa}$ subsynaptic protein (Baldwin et al., 1988; Froehner, 1989), of myogenin gene family members (Eftimie et al., 1991), and of the cell adhesion protein N-CAM (Couvault and Sanes, 1985; Rieger et al., 1985; Sanes, 1989). An early macroscopic reaction at an inactivated $\mathrm{nmj}$ is the local proliferation of muscle interstitial cells, mainly fibroblasts (Murray and Robbins, 1982; Connor and McMahan, 1987; Gatchalian et al., 1989). Proliferation is a transient phenomenon: it is first detected about $24 \mathrm{hr}$ after denervation and it peaks $2 \mathrm{~d}$ after denervation. The proliferation reaction is most prominent in the vicinity of the inactive $n m j$ and proliferating cells may contribute to the regenerative process, for example, by producing cell recognition molecules (Couvault and Sanes, 1985; Rieger et al., 1985; Sanes et al., 1986; Bixby et al., 1987; Connor and McMahan, 1987; Gatchalian et al., 1989). Intramuscular nerve sprouting can first be detected about $4 \mathrm{~d}$ after muscle inactivation. In the neuromuscular system sprouting may be promoted by diffusible substances, but local sprouting at the neuromuscular junction may involve clevated expression of acetylcholine receptor (Pestronk and 
Drachmann, 1985). Elevated levels of neurite growth-promoting activities were detected in soluble protein extracts from denervated muscle (Henderson et al., 1983). Appearance time and lcvels of these putative sprout-inducing activities correlated with the sprouting reaction in vivo. The identity and cellular source of the sprouting activities is presently not known. On the other hand, since dramatic changes in the extracellular and cell surface protein environment also correlate with the sprouting reaction (Couvault and Sanes, 1985; Rieger et al., 1985; Sanes, 1989), it is presently not clear whether growth factortype molecules must interact with intramuscular nerves to promote sprouting. What is clear, however, is that an initial signal (or signals) from the inactive skeletal muscle fibers must initiate the restorative cell reactions. The identity of the signal is not known and the identification of a candidate molecule for this signaling role is the object of this study.

Insulin-like growth factors (IGFs) (Nissley and Rechler, 1984; Froesch et al., 1985) have a wide range of action in muscle development and growth (Florini et al., 1991), and may be involved, directly or indirectly, in the sprouting reaction of the neuromuscular system: (1) these factors promote neurite growth in vitro (Recio-Pinto et al., 1986), including growth and branching of neurites from embryonic motoneurons (Caroni and Grandes, 1990); (2) overall IGFI and IGF2 mRNA levels are upregulated in denervated or paralyzed skeletal muscle and downregulated after the reestablishment of neuromuscular transmission (Glazner and Ishii, 1989; Ishii, 1989); (3) exposure of adult muscle to elevated levels of IGFs by a nonlesioning protocol is sufficient to induce some of the reactions observed in inactivated muscle, including the proliferation of interstitial cells, and intramuscular nerve sprouting (Caroni and Grandes, 1990).

In this study we have determined the time course of the IGF response and the cellular source of the elevated IGF mRNA and protein in inactivated muscle. The biological effects of IGFs are affected by the presence of specific soluble extracellular proteins (IGF-binding proteins, or IGF-BPs) that bind the growth factors with affinities comparable to or higher than those of the relevant cellular receptor, that is, the IGF1 receptor (IGF1-R) (Nissley and Rechler, 1984; Froesch et al., 1985; Rechler and Nissley, 1985; Baxter and Martin, 1989; Yang et al., 1989). Although the role(s) of IGF-BPs is presently unclear, they are able to sequester the growth factors in the extracellular space, preventing binding and activation of the IGFl-R (Zapf et al., 1979; Kuoner and Smith, 1980; Froesch et al., 1985). Therefore, to determine whether IGFs may be involved in early cellular responses to muscle inactivation, we locally applied recombinant IGF-BP5 or IGF-BP4 to paralyzed muscle and monitored its effects on the interstitial cell proliferation reaction.

We report that an early response in paralyzed muscle is the transient elevation of muscle fiber IGFI mRNA. This response, accompanied by elevated levels of intramuscular IGF1 protein, coincides with or slightly precedes the interstitial cell proliferation reaction. Furthermore, local applications of IGF-BP5 or IGF-BP4 to paralyzed muscle largely prevented the stimulation of interstitial cell proliferation, indicating that muscle IGFs are involved in this reaction. We therefore hypothesize that transiently elevated intramuscular IGF1 may be an early signal from inactivated muscle fibers to initiate regenerative reactions. These may include autocrine stimulation of skeletal muscle fibers, the local proliferation of interstitial cells, and intramuscular nerve sprouting.

\section{Materials and Methods}

Reagents and tissues. Digoxigenin-UTP, digoxigenin-dUTP, and alkaline phosphatase-conjugated anti-digoxigenin antiserum were from Boehringer Mannheim, Mannheim, Germany. Recombinant human IGF1 was a kind gift from J. A. Fischer (University of Zurich, Switzerland), and rat MSA (IGF2) was from Collaborative Research Inc., Bedford, MA. Purified recombinant human IGF-BP5 and IGF-BP4 were a kind gift of J. Zapf (University of Zurich, Switzerland). Purified botulinum toxin A was a kind gift from V. Witzeman (Max Planck Institute, Heidelberg, Germany). ${ }^{3} \mathrm{H}$-thymidine (methyl- ${ }^{3} \mathrm{H}$-thymidine, $20 \mathrm{Ci} / \mathrm{mmol}$ ) was from New England Nuclear, Boston, MA. Colored molecular weight standards (Rainbow) were from Amersham Intl. plc. Amersham, UK. Rabbit antiserum to human recombinant IGF1 was a kind gift from G. Roemmele, K. Mueller, and C. Heusser (Ciba-Geigy Corp., Basel, Switzerland). The antibody specifically detects human, bovine, and rat IGFI on Western blots and on radioimmunoassay (RIA); it cross-reacts weakly with IGF2 (less than 300 -fold weaker binding to IGF2 on Western blots) (see also Fig. 2). Monoclonal antibody against neurofilament-160 was from Sigma. Rhodamine (RITC)- $\alpha$-bungarotoxin, biotin-conjugated goat anti-rabbit antiserum, Lucifer yellow-conjugated streptavidin, and DAPI (4',6-diamino-2-phenylindole hydrochloride) were from Molecular Probes Inc., Eugene, OR. ALZET osmotic minipumps (model 1007D) were from ALZA Corp., Palo Alto, CA. Oligonucleotides were synthesized using an Applied Biosystems 308B DNA synthesizer.

Six-month-old BALB/c mice and 4-d- to 6-month-old Lewis rats were used for the experiments of this study. Animals were anesthetized with ether and then injected subcutaneously with $20-100 \mu \mathrm{l}$ of $0.1 \%$ BSA in PBS with or without (contralateral side) $50 \mathrm{pg}$ (mice), $200 \mathrm{pg}$ (1-monthold rats), or $400 \mathrm{pg}$ (6-month-old rats) of purified botulinum toxin A. Where indicated, IGF-BP5 ( $1 \mu \mathrm{g}$ in $50 \mu \mathrm{l}$ of $0.1 \% \mathrm{BSA}$ in PBS) was applicd to mice immediately following botulinum toxin $A$, and applications were repeated 1 and $2 \mathrm{~d}$ after paralysis. IGF-BP4 was diluted to a final concentration of $100 \mu \mathrm{g} / \mathrm{ml}$ in PBS with $0.1 \%$ BSA and applied with an osmotic minipump $(1.5 \mathrm{~cm}$ length; inner volume of $100 \mu \mathrm{l}$; rate of delivery, $11 \mu \mathrm{l} / \mathrm{d}$ ). The pump was implanted subcutaneously over the gluteus muscle just before application of the botulinum toxin. Attention was paid to the positioning of the minipump: this was implanted anterior relative to the gluteus muscle, parallel to the body axis, about $0.5-1 \mathrm{~cm}$ laterally from the vertebrae column, and with its opening slightly anterior of the femur. Handling of the pumps was according to the recommendations of the manufacturer.

All injections were applied directly on top of the gluteus muscle and special care was taken not to contact the underlying tissue with the injection needle. The first paralysis signs were visible within $12 \mathrm{hr}$ and local paralysis was obvious (dragging of one hind limb with preserved motility of the corresponding distalmost muscles) after $24 \mathrm{hr}$. No paralysis signs were detectable at any time outside the botulinum injected hind limb. In control experiments one hind limb of 1-month-old rats was denervated by sciatic nerve transection. In this case, the corresponding soleus muscles were analyzed. After appropriate times animals were anesthetized with ether and killed by cervical dislocation or decapitation, and muscles and/or spinal cords were collected and further processed. To verify that muscles had been paralyzed some muscle samples were processed for RNA collection and Northern blot analysis of acetylcholine receptor $\alpha$-subunit. In botulinum toxin-treated muscles receptor $\alpha$-subunit message was strongly induced, whereas little induction of actin mRNA was detected over control muscles (data not shown). For in situ hybridization, muscles were immediately frozen in liquid nitrogen. For immunocytochemistry experiments or for the detection of incorporated ${ }^{3} \mathrm{H}$-thymidine, muscles were fixed overnight at $4^{\circ} \mathrm{C}$ in freshly prepared $4 \%$ paraformaldehyde in PBS, and cryoprotected by a $5 \mathrm{hr}$ incubation at $4^{\circ} \mathrm{C}$ in $20 \%$ sucrose in PBS.

Hybridization probes. Rat IGFI and IGF2 coding sequences were produced with the polymerase chain reaction from postnatal day 14 (P14) rat liver first-strand cDNA (polyA primed). A 327 base pair (bp) IGF1 coding sequence (Murphy et al., 1987; from nucleotide 1 to 327) was amplified with the primers 5'-CTACGAATTCTAGGTCTTGTTTCCTGCACTTCC- $3^{\prime}$ (antisense) and 5'-GCCAGGATCCGACCAGAGACCCTTTGCGGGGCT-3' (sense); a 542 bp IGF2 coding sequence (Dull et al., 1984; from nucleotide 1058 to 1600) was amplified with the primers 5'-AATTGAATTCACTGATGGTTGCTGGA-3' (antisense), and 5'-ATGGGGATCCCAGTGGG-3' (sense). DNAs of the expected size werc cloned in the expression vector pSPT 19 (Boehringer Mannheim) and their identities with the published rat sequences 
were verified. Double-stranded sequencing was performed with the Sequenase 2 kit (U.S. Biochemical Corp., Cleveland, OH) using SP6 and T7 primers. Transcription reactions were performed as recommended by the manufacturer (Boehringer Mannheim) in the presence of a 2:1 mixture of UTP:digoxigenin-UTP. Digoxigenin-labeled sense and antisense probes were hybridized to rat liver polyA ${ }^{+}-$RNA on a Northern blot, and the specific detection by the antisense probes, but not the sense probes, of multiple RNA species of the expected sizes (Brown et al., 1986; Ballotti et al., 1987) was verified with the alkaline phosphataseconjugated anti-digoxigenin antibody. In addition, both antisense and sense probes detected the original polymerase chain reaction products on a Southern blot, indicating that the sense probes had been synthesized.

In situ hybridization protocols. The usual precautions were taken to avoid RNA degradation throughout the procedures described in the following paragraph. Frozen muscle tissues were mounted and cut in $12 \mu \mathrm{m}$ sections in a cryostat. Sections were rapidly collected onto polylysine-coated slides and immediately laid onto pulverized dry ice with the section side up (Beck et al., 1987). After 30 min on dry ice, sections were fixed for $15 \mathrm{~min}$ at $4^{\circ} \mathrm{C}$ with freshly prepared $4 \%$ paraformaldehyde in PBS. Slides were then rinsed three times in PBS and exposed to 20 $\mu \mathrm{g} / \mathrm{ml}$ of self-digested proteinase $\mathrm{K}$ (Sigma) in $50 \mathrm{~mm}$ Tris, $5 \mathrm{~mm}$ EDTA, $\mathrm{pH} 7.4$, at room temperature for $10 \mathrm{~min}$. Sections were then rinsed once in PBS, immediately postfixed for $5 \mathrm{~min}$ at room temperature in paraformaldehyde as described above, rinsed three times in PBS, dehydrated, and hybridized to probe on the same day. In some cases, to improve hybridization to RNA in muscle interstitial cells, the protease treatment was performed with $5 \mu \mathrm{g} / \mathrm{ml}$ of proteinase $\mathrm{K}$ for $5 \mathrm{~min}$.

Dehydrated, dried sections were hybridized overnight at $56^{\circ} \mathrm{C}$ in hybridization buffer [ $50 \%$ formamide, $4 \times \mathrm{SSC}(1 \times \mathrm{SSC}$ is $150 \mathrm{~mm} \mathrm{NaCl}$, $15 \mathrm{~mm}$ sodium-citrate, $\mathrm{pH} 7.0$ ), $10 \mathrm{~mm}$ sodium-phosphate, $\mathrm{pH} 7.0,1$ mM FDTA, $100 \mathrm{mg} / \mathrm{ml}$ yeast RNA (Sigma), $2 \times$ Denhardt's] containing $0.5 \mu \mathrm{g} / \mathrm{ml}$ of digoxigenin-labeled riboprobe. The washing procedure was as follows: three times $15 \mathrm{~min}$ at $56^{\circ} \mathrm{C}$ in $0.2 \times \mathrm{SSC}$; one rinse in STE $(100 \mathrm{~mm} \mathrm{NaCl}, 10 \mathrm{~mm}$ Tris, $1 \mathrm{~mm}$ EDTA, $\mathrm{pH} 8.0) ; 15 \mathrm{~min}$ at $37^{\circ} \mathrm{C}$ in STE with $10 \mu \mathrm{g} / \mathrm{ml}$ of RNase A (Boehringer Mannheim); $3 \times 10 \mathrm{~min}$ at $37^{\circ} \mathrm{C}$ in $0.1 \times \mathrm{SSC}$. Sections were finally incubated for $10 \mathrm{~min}$ in blucking buffer, cursisting of $150 \mathrm{~mm} \mathrm{NaCl}, 100 \mathrm{~mm}$ Tris, $\mathrm{pH} 8.5,5 \%$ BSA, and then for $1 \mathrm{hr}$ in the same buffer with a 1:750 dilution of alkaline phosphatase-conjugated anti-digoxigenin antibody (Boehringer Mannheim). Unbound antibody was then removed by three $5 \mathrm{~min}$ washes in blocking buffer, slides were equilibrated for $3 \mathrm{~min}$ in color reaction buffer ( $100 \mathrm{~mm} \mathrm{NaCl}, 100 \mathrm{~mm}$ Tris, pH 9.5, $50 \mathrm{~mm} \mathrm{MgCl}_{2}$ ), and the color reaction was then performed for durations varying from $20 \mathrm{~min}$ to $6 \mathrm{hr}$, as recommended by the manufacturer. All samples from one experiment were treated in parallel, and complete sets of experiments were repeated at least three times for each series of animals; three series of animals were processed independently for each experiment, and representative data from one experimental set are shown in each figure. Relative signal intensities among the experimental points of one experimental set were reproducible. However, overall signal intensities varied slightly from one set of experiments to the other, and this was partially compensated for by adjusting the color reaction time; the color reaction time was, however, identical for all samples from one experimental set, including the corresponding sense controls. Stained sections were dehydrated, passed through xylole, mounted in DePeX (BDH Ltd., Poole, UK), and viewed under bright-field illumination. All samples from one experiment were photographed and processed in exactly the same way, to allow for direct comparison of signal intensities.

Immunocytochemistry and detection of intramuscular cell division. After fixation and cryoprotection, $12 \mu \mathrm{m}$ cryostat sections were prepared from dissociated muscle tissue. All subsequent manipulations were performed at room temperature. Sections were incubated for $30 \mathrm{~min}$ in PBS with 5\% BSA, and then in the same buffer for $2 \mathrm{hr}$ with either a 1:2000 dilution of rabbit anti-IGFI antiserum, or with the same dilution of a nonimmune rabbit serum. For some control experiments the diluted IGF1 antiserum was preincubated for $2 \mathrm{hr}$ at room temperature in the presence of $20 \mu \mathrm{g} / \mathrm{ml}$ of recombinant human IGFl, and then applied to the sections. Unbound antibody was removed by three washes in PBS with $1 \% \mathrm{BSA}$; the sections were then incubated for $30 \mathrm{~min}$ in the same buffer with biotin-conjugated goat anti-rabbit antiserum $(1: 300$ dilution), washed three times as described above, incubated for $30 \mathrm{~min}$ in the presence of Lucifer yellow-conjugated streptavidin (1:300 dilution), washed three times, and mounted for fluorescence microscopy. Where required, RITC $-\alpha$-bungarotoxin was included in the second an- tibody solution. Fluorescence was viewed with appropriate filters with an Axiovert 10 microscope (Carl Zeiss AG, Zurich, Switzerland).

Cell division was compared in paralyzed and in control mouse muscles by twice injecting intraperitoneally $50 \mu \mathrm{Ci}$ of ${ }^{3} \mathrm{H}$-thymidine. Injections were applied $12 \mathrm{hr}$ and $3 \mathrm{hr}$ before the mice were killed. Muscles were fixed in $4 \%$ paraformaldehyde in PBS and $12 \mu \mathrm{m}$ cryostat sections were cut. Emulsion (NTB-2, Eastman Kodak Co.) exposure was for 14 $\mathrm{d}$ and developed sections were counterstained with cresyl violet. Sections were examined under bright-field illumination and labeled nuclei were counted. To compare nuclei numbers at different distances from the nmj, muscle sections were labeled with RITC- $\alpha$-bungarotoxin, counterstained with the nuclear stain DAPI, and viewed with appropriate fluorescence filters.

A protein fraction enriched in rat IGFl was prepared from adult rat serum by acetic acid extraction, followed by sephadex G75 chromatography, as described (Rinderknecht and Humbel, 1976). Immunoblots for the detection of IGFs were performed after separation of the proteins by SDS-PAGE and transfer to Immobilon-matrix (Millipore). Rabbit anti-IGFI antiserum (or a nonimmune rabbit antiserum) was diluted 2000 -fold and bound antibody was detected with alkaline phosphataseconjugated goat anti-rabbit (Boehringer Mannheim).

\section{Results}

Early and transient elevation of muscle fiber IGFI $m R N A$ in paralyzed muscle

When 1-month-old rats were injected subcutaneously with 200 $\mathrm{pg}$ of botulinum toxin $\mathrm{A}$, producing unilateral paralysis of the gluteus and underlying muscles due to the prevention of $\mathrm{Ca}^{2+}$ induced quantal release of ACh (Kao et al., 1976; Thesleff, 1989), muscle fiber IGF1 mRNA levels rose rapidly: elevated levels were already detectable $12 \mathrm{hr}$ (but not $7 \mathrm{hr}$ ) after exposure to the toxin, and reached peak levels after about 1.5-2 d (Fig. 1). At later time points, muscle fiber IGF1 mRNA declined to intermediate levels and elevated levels were then also detected in intramuscular connective layers (see Fig. $3 c$ ). The data of Figure 1 also demonstrate that the IGF1 mRNA reaction was a local response to the effects of the toxin, since no such changes were detected in the corresponding contralateral muscle that had been only exposed to carrier (Fig. $1 h$ ). Similar findings were obtained upon denervation of one hind limb by transection of the sciatic nerve (soleus muscle data of Fig. 2), indicating that induction of IGFI mRNA was due to the lack of muscle activation. Paralysis or denervation did not only affect IGFI mRNA but also led to elevated levels of the corresponding protein (Fig. 2 ). In addition, similar findings were obtained in 6-month-old mouse gluteus muscle (Fig. 3), indicating that the IGF1 reaction was not restricted to rat muscle or to juvenile animals. In agreement with the time course of the IGFl mRNA response in rat muscle, highest levels of IGF1-immunoreactive material were detected around either rat or mouse muscle fibers $2-3 \mathrm{~d}$ postparalysis (data of Fig. 3 for mouse muscle; rat muscle data not shown). The data of Figures 1 and 3 suggest that IGFl mRNA and protein levels in muscle evolved in a similar manner, involving a rapid increase to peak values after 2-3 d, followed by stabilization at an intermediate level significantly higher than in untreated muscle.

Proliferation of interstitial cells and nerve sprouting in inactive muscle are more prominent in the vicinity of the inactive end plates. We therefore determined whether elevated IGF1 immunoreactivity could be detected in perisynaptic spaces. As shown in Figure 2, some accumulation of the IGFI signal did coincide with neuromuscular junctions. However, this moderate concentration of the IGFl signal was apparently restricted to the neuromuscular junction itself, and no decline of IGFI im- 

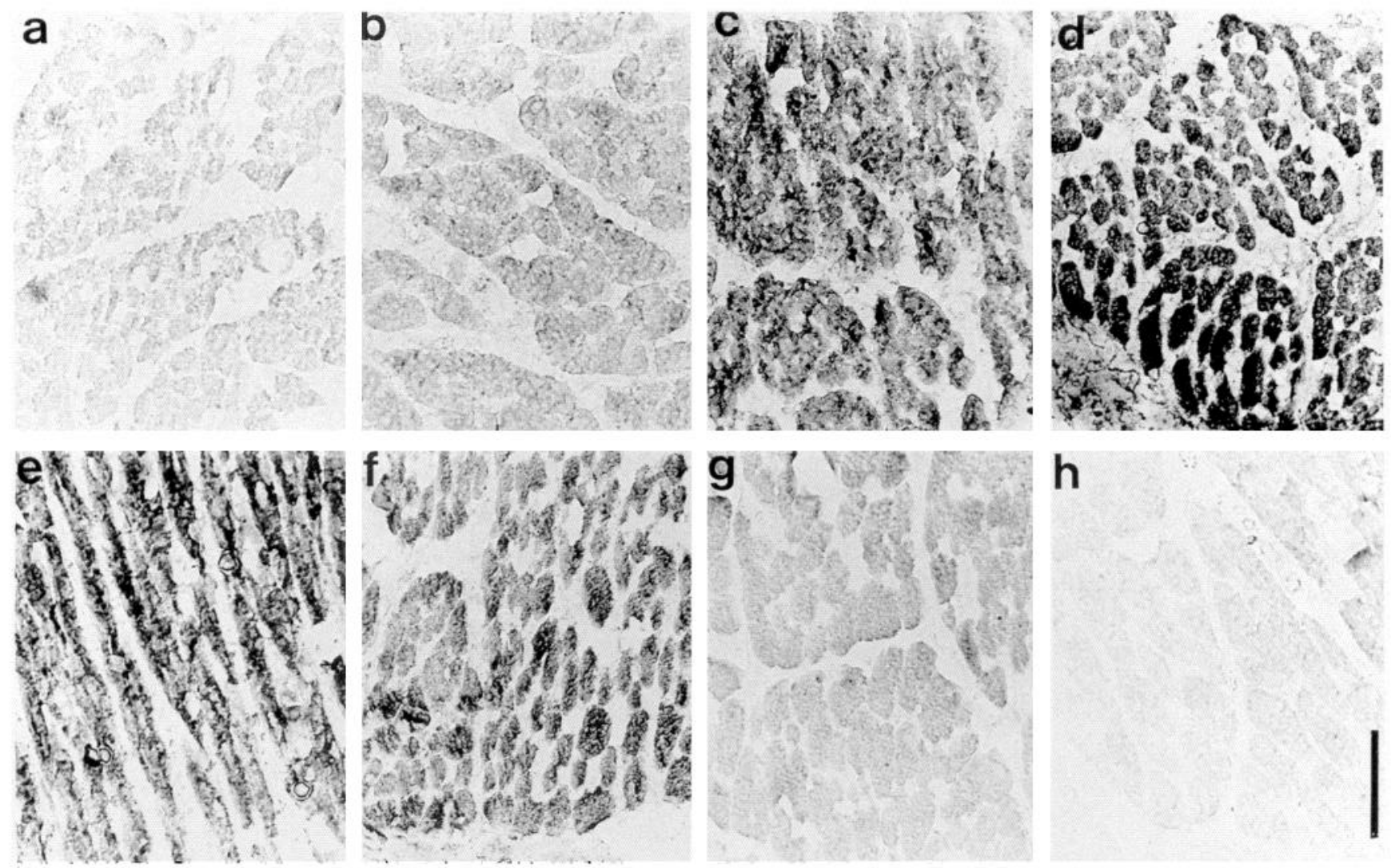

Figure 1. Rapid and transient elevation of IGF1 mRNA in skeletal muscle fibers of botulinum toxin-paralyzed 1-month-old rat gluteus muscle. Duration times from the injection of toxin to collection of the muscles were, for $a, 7 \mathrm{hr} ; b, 12 \mathrm{hr} ; c, 22 \mathrm{hr} ; d, 36 \mathrm{hr} ; e, 48 \mathrm{hr} ; f, 3 \mathrm{~d} ; g, 5 \mathrm{~d} ; h, 36$ $\mathrm{hr}$ (contralateral muscle from same animal as in $d$, exposed to carrier without toxin). The signal intensity in $a$ was not significantly higher than in control untreated muscle. Data from one representative experiment; comparable relative signal intensities were detected in five analogous experiments. Scale bar, $75 \mu \mathrm{m}$.

munoreactivity along muscle fibers consistently correlated with the distance from the end-plate region. That the neuromuscular junction region may be a preferred site of IGF1 binding is indicated by the accumulation of locally applied IGF1 in its vicinity (Fig. 2, bottom). The figure also shows codistribution of IGF1 immunoreactivity with neurofilament-positive neuronal processes, suggesting accumulation of the growth factor at motoneuron processes or Schwann cells.

In conclusion, an early response in paralyzed skeletal muscle is a rapid and transient elevation of IGF1 mRNA and protein levels. The IGF1 mRNA response is a muscle fiber reaction, implying that an early response in paralyzed skeletal muscle fibers is the release of markedly elevated amounts of IGF1.

The response of muscle IGF2 mRNA to paralysis lacked the rapid and transient muscle fiber elevation that had been detected for the IGF1 message: as shown in Figures 2 and 4, no obvious changes in IGF2 mRNA levels were detected $2 \mathrm{~d}$ after denervation or paralysis. Rather, a slower but persistent elevation of the IGF2 message was detected in connective tissue cells and in muscle fibers. This response reached maximal levels at about $8 \mathrm{~d}$ postparalysis and a similar slow response was observed for the IGF1 message in connective tissue cells. Therefore, after skeletal muscle inactivation, a rapid and transient elevation in muscle fiber-derived IGF1 is followed by a slower, persistent, and generalized elevation of the IGF2 message.
Possible IGFI-responsive systems in paralyzed muscle: time course of interstitial cell proliferation and its prevention by local applications of IGF-BP5 or IGF-BP4

Both partial denervation and botulinum toxin-induced paralysis are followed by an intramuscular nerve sprouting reaction (Brown et al., 1981; Holland and Brown, 1981). We therefore determined whether botulinum toxin-induced paralysis also caused an early interstitial cell proliferation reaction.

As shown in Table 1, toxin-induced paralysis had a similar effect on intramuscular cell proliferation as was described by others after denervation-induced paralysis (Murray and Robbins, 1982; Connor and McMahan, 1987; Gatchalian et al., 1989). As in denervated muscle, the cell proliferation response was rapid in onset, peaked at about 2-3 d after toxin injection, and was essentially completed after $8 \mathrm{~d}$ of paralysis. In addition, like in denervated muscle, the proliferation reaction in toxinparalyzed muscle was slightly more prominent in the vicinity of nmjs. These data support the interpretation that the proliferation reaction in denervated muscle was not due to the presence of disconnected intramuscular nerves (Murray and Robbins, 1982; Connor and McMahan, 1987; Gatchalian et al., 1989) but, like in toxin-paralyzed muscle, to inactivation of neuromuscular transmission. Cell proliferation coincided with the early muscle fiber IGF1 response, suggesting that elevated 

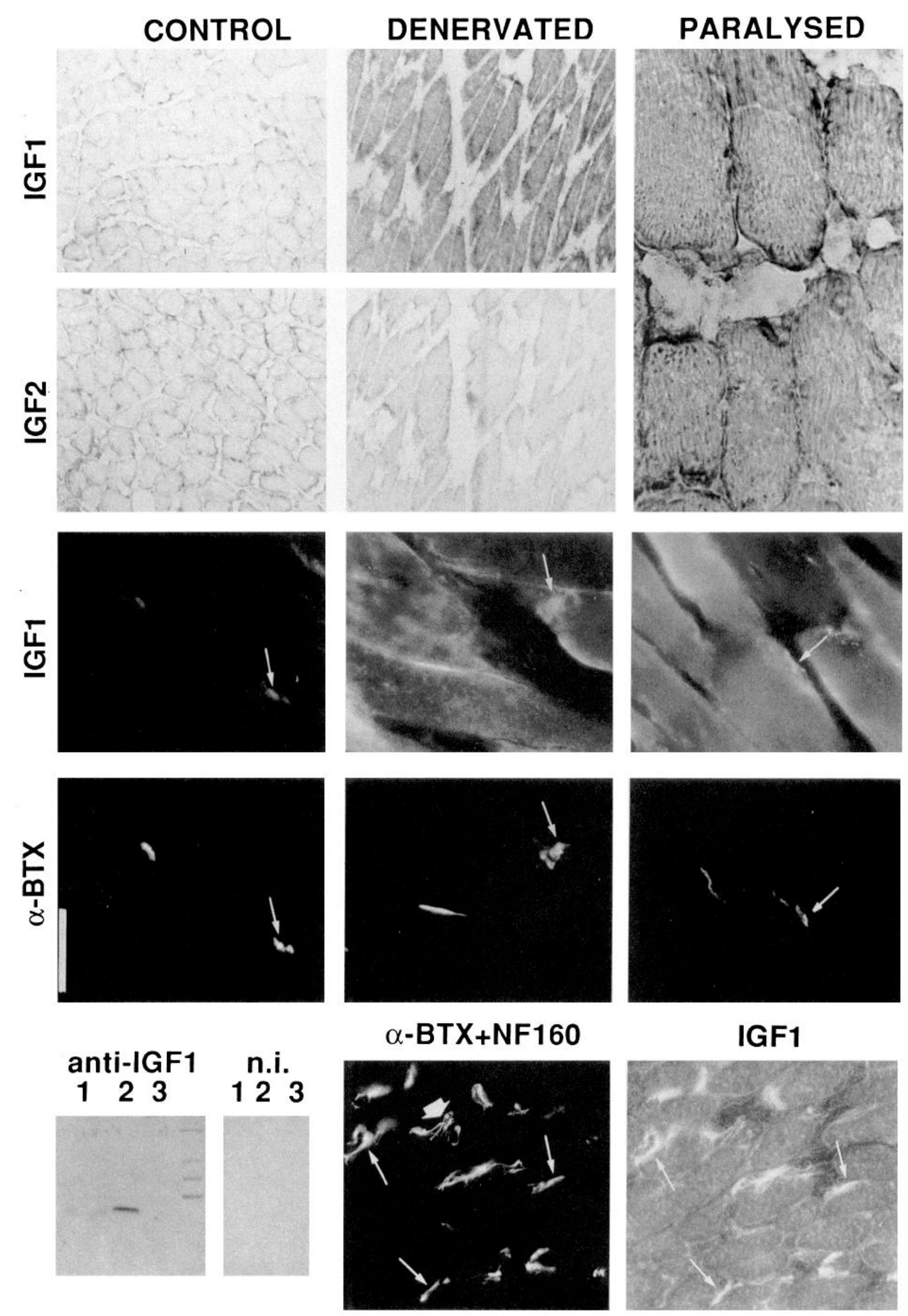

IGF1

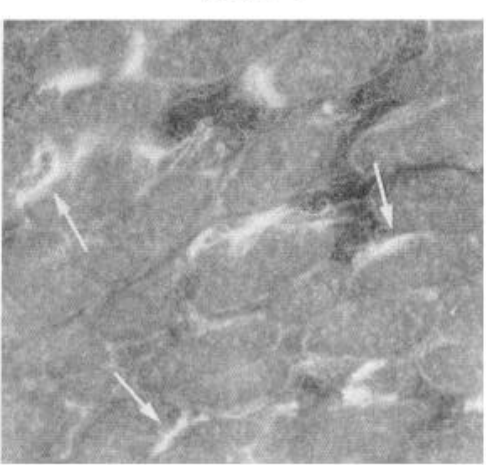


intramuscular IGF1 in chronically inactive muscle might induce the interstitial cell proliferation response.

To determine whether muscle IGFs are involved in the proliferation reaction, we applied human recombinant IGF-BP5 or IGF-BP4 to paralyzed muscle. IGF-BP5 was applied subcutancously at the same site as the toxin. For these experiments, the effects of the binding protein were assayed at the time of maximal thymidine incorporation (2.5 d postparalysis). IGFBP4 was delivered locally and continuously for $7 \mathrm{~d}$ with an osmotic minipump. Binding protein doses were estimated to achieve at least 10 -fold molar excess over IGFs, assuming that concentrations of the latter would reach peak values of $100 \mathrm{ng} /$ Inl of tissue, that is, values comparable to those detected in the liver, the main producer of serum IGFs. A 10 -fold molar excess of IGF-BP5 or IGF-BP4 over IGFs specifically produces more than $95 \%$ inhibition of the mitogenic activity of IGFs in tissue culture assays (Kiefer et al., 1992). As shown in Figure 5, the IGF-BPs essentially abolished elevated interstitial cell proliferation in paralyzed muscle. These findings therefore demonstrate that IGFs are essential to the elevated interstitial cell proliferation reaction in paralyzed muscle.

\section{Discussion}

The main findings of this study are that an early consequence of presynaptic inactivation at the $\mathrm{nmj}$ is the production of the growth factor IGFl by the postsynaptic muscle fiber, and that muscle IGFs are essential to the interstitial cell proliferation reaction in inactivated muscle. When combined with our previous finding that application of IGFs to otherwise untreated adult skeletal muscle is sufficient to induce interstitial cell proliferation, these findings support the hypothesis that muscle fiber-derived IGFl plays an important signaling role in inactivated muscle. After the initial IGF1 burst, IGF2 mRNA is also elevated in inactive muscle; this situation is reminiscent of the reinduction of several development-associated $m$ RNAs in denervated and paralyzed muscle (Laufer and Changeux, 1989), and may reflect elevated remodeling and growth requirements in these muscles.

\section{Methodological aspects}

The aim of this study was to determine whether IGFs qualified as possible early signaling molecules from inactive muscle to initiate restorative reactions. In most experiments we used botulinum toxin $\mathrm{A}$ to inactivate neuromuscular transmission since this proccdure blocks calcium-induced quantal release of $\mathrm{ACh}$,
Table 1. Timing and location of the cell division response in botulinum toxin-paralyzed skeletal muscle

\begin{tabular}{|c|c|c|c|}
\hline \multirow[b]{2}{*}{$\begin{array}{l}\text { Time after botulinum } \\
\text { toxin injection }\end{array}$} & \multirow{2}{*}{$\begin{array}{l}\text { Intra- } \\
\text { muscular } \\
\text { interstitial } \\
\text { cells incor- } \\
\text { porating } \\
\text { thymidine } \\
(\%)\end{array}$} & \multicolumn{2}{|c|}{$\begin{array}{l}\text { Number of nuclei } \\
\text { per field }\end{array}$} \\
\hline & & $\begin{array}{l}\text { Within } \\
100 \mu \mathrm{m} \\
\text { from } \mathrm{nmjs}\end{array}$ & $\begin{array}{l}\text { More } \\
\text { than } \\
200 \mu \mathrm{m} \\
\text { from } \mathrm{nmj}\end{array}$ \\
\hline No injection & 0.45 & 52 & 40 \\
\hline $2 \mathrm{~d}$, contralateral & 0.38 & 47 & 36 \\
\hline $1 \mathrm{~d}$ & 1.1 & 58 & 38 \\
\hline $2 d$ & 8.5 & 71 & 51 \\
\hline $3 d$ & 6.3 & 95 & 61 \\
\hline $5 \mathrm{~d}$ & 2.9 & 112 & 63 \\
\hline $8 \mathrm{~d}$ & 1.5 & 142 & 75 \\
\hline
\end{tabular}

Six-month-old micc reccived $50 \mathrm{pg}$ of botulinum toxin $\mathrm{A}$ in $50 \mu \mathrm{l}$ of carrier over the right gluteus (paralyzed side) and $50 \mu$ l of carrier over the left gluteus muscle (contralateral side). After indicated times animals were killed and gluteus maximus examined. Thymidine-incorporating cells were counted on cross-sectioned muscle. Values are averages, with standard errors between $5 \%$ and $10 \%$; approximately 1000 nuclei from randomly selected fields were analyzed per animal $(N=3)$. DAPI-positive nuclei were counted at $500 \times$ magnification (one plane of focus, $12 \mu \mathrm{m}$ sections); one field was defined as a $200 \times 200 \mu \mathrm{m}$ square either with a line of nmjs running across its center, or with no nmjs within $200 \mu \mathrm{m}$ from its boundaries. Values are averages, with standard errors of about $10 \%$; three to five fields were counted per animal $(N=3) .2 \mathrm{~d}$, contralateral: muscle from same animals as $2 \mathrm{~d}$ botulinum, but exposed to carrier.

but does not affect intramuscular cells (Kao et al., 1976; Thesleff, 1989), and it avoids the production of degenerating nerve fragments that might activate inflammatory side-reactions. Botulinum toxin-induced paralysis elicits a massive sprouting reaction in intramuscular nerves (Brown et al., 1981; Holland and Brown, 1981) and, as we show in this study, it is also followed by an interstitial cell proliferation reaction. This reaction resembled the proliferation reaction after denervation. Since nerve sprouting and other inactivation-induced reactions can be prevented by direct electrical stimulation of the muscle, it is most likely that in all inactivation protocols the crucial restorative reaction triggering factor is prolonged muscle inactivity (Brown, 1984; Sanes and Couvault, 1985).

The nonradioactive detection method of hybridized nucleic acid probes used in this study allows a resolution of the signal at the cellular level. In agreement with the Northern blot data of Ishii (1989), we found that both IGF1 and IGF2 mRNA are downregulated to very low adult levels during the second post-

\footnotetext{
Figure 2. Elevation of IGFl mRNA and protein levels in rat skeletal muscle $2 \mathrm{~d}$ after muscle inactivation, and accumulation of exogenous IGFI at the neuromuscular junction. Induction of IGFI in inactivated muscle is demonstrated in the top four rows. Data are from 1-month-old animals. One hind limb was either denervated (central column; Control column is from corresponding contralateral untreated muscle) or paralyzed locally with botulinum toxin A (right column). Two days after the treatments the soleus (denervation) or gluteus (toxin-induced paralysis) muscle was collected and analyzed. Upper two rows, IGF mRNAs; lower two rows, double labeling for IGFI and $\alpha$-bungarotoxin. A higher-magnification view of an in situ hybridization experiment with the IGFI probe is shown for the paralyzed muscle (top two rows, right). Note elevated IGFI mRNA and protein in denervated and paralyzed muscle. Arrows point to examples of elevated IGFI immunoreactivity at neuromuscular junctions of control and inactivated muscles. The immunoblots shown in the lower left two panels were reacted with either rabbit anti-IGFl antiserum (anti$I G F l$, left $)$ or nonimmune rabbit serum (n.i., right). Lane 1, One microgram of IGFl-enriched G75 fraction from acid-extracted adult rat serum (Rinderknecht and Humbel, 1976; this sample contains approximately $20 \mathrm{ng}$ of rat IGF1); lane 2, $10 \mathrm{ng}$ of recombinant human IGFl; lane 3, 400 ng of rat IGF2. The three lowest molecular weight standards on the right side of the anti-IGF1 blot are 14,21, and $30 \mathrm{kDa}$. Note that the antiserum produced against human IGFl cross-reacted with rat IGFl (detection weaker than that of human IGFI), but did not detect a 20-fold excess of rat IGF2. Lower right two panels demonstrate accumulation of exogenous IGFI at the neuromuscular junction. Recombinant human IGF1 was applied daily to rat gluteus muscle from P10 to P13. Cryostat sections were double labeled for $\alpha$-bungarotoxin plus neurofilament-160 (left) and IGF1 (right). In the left panel, larger labeled structures (thin arrows) are neuromuscular junctions, and thin filaments (large arrow) are nerves. Scale bar: $120 \mu \mathrm{m}$ for in situ hybridization experiments; $18 \mu \mathrm{m}$ for higher-magnification photograph; $35 \mu \mathrm{m}$ for immunocytochemistry experiments, rows 3 and $4 ; 100 \mu \mathrm{m}$ for detection of exogenous IGF1.
} 

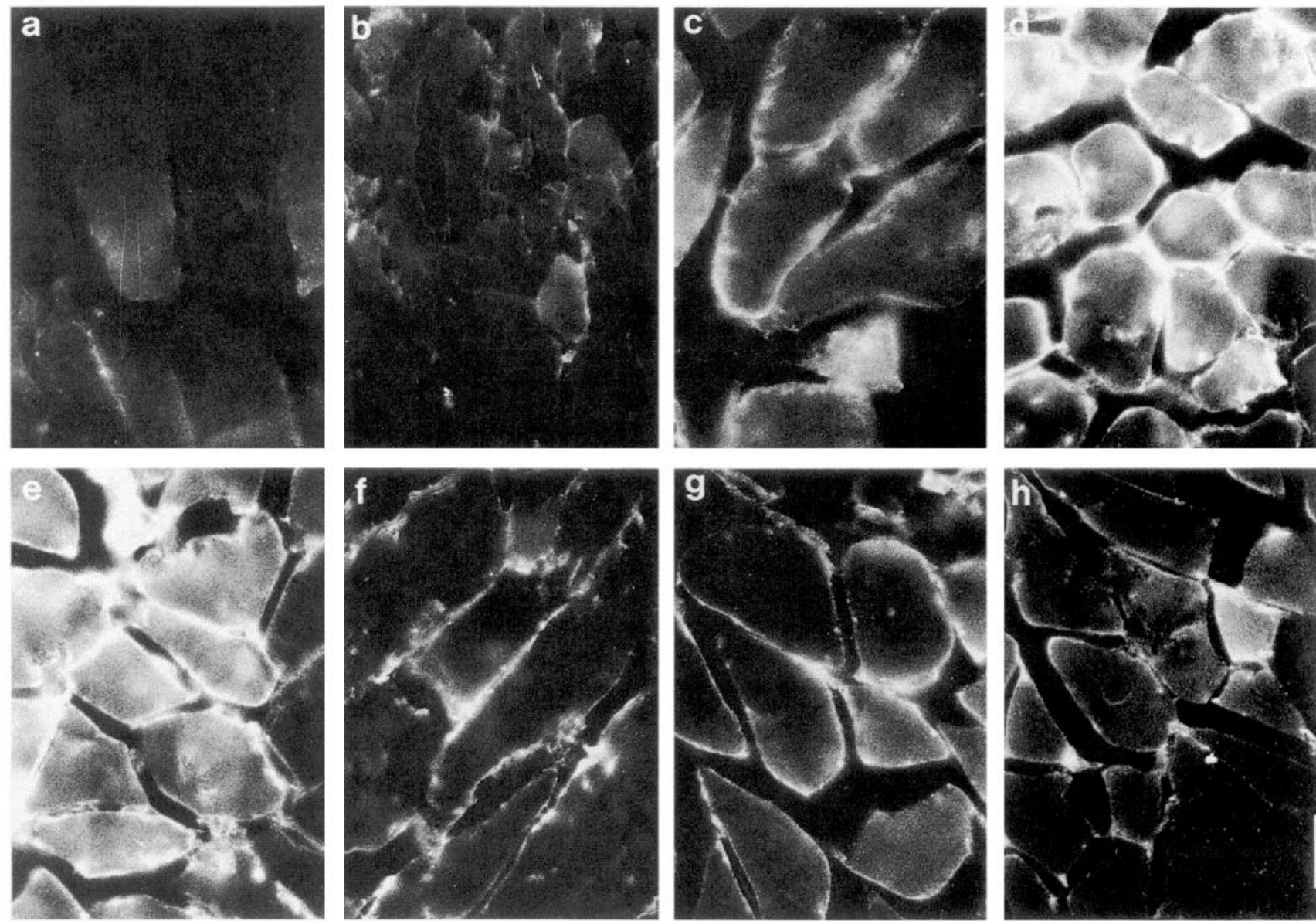

Figure 3. Rapid and transient elevation of IGF1 immunoreactivity in botulinum toxin-paralyzed 6-month-old mouse gluteus muscle. $b-h$, IGF1 immunoreactivity in muscle $7 \mathrm{hr}(b), 24 \mathrm{hr}(c), 48 \mathrm{hr}(d), 3 \mathrm{~d}(e), 4 \mathrm{~d}(f), 5 \mathrm{~d}(g)$, and $8 \mathrm{~d}(h)$ after toxin injection. $a$ is like $d$ but antiserum was preadsorbed with $20 \mu \mathrm{g} / \mathrm{ml}$ of recombinant human IGF1. IGF1-immunoreactive material was mainly detectable near the surface of skeletal muscle fibers. Data are from one representative experiment; comparable relative signal intensities were detected in three analogous experiments. Scale bar, $25 \mu \mathrm{m}$.

natal week (data not shown). We confirmed that IGFs are expressed in muscle (see also Beck et al., 1987; Han et al., 1987), and could show that both muscle fibers and muscle connective tissue cells express IGF messages. Our data demonstrate that an early increase of IGFl mRNA after denervation or paralysis takes place in muscle fibers. It is, however, important to point out that conditions for optimal detection of messages in muscle fibers and in nonmuscle cells were not the same: more prolonged protease pretreatment of the muscle sections was required for the detection of mRNAs in muscle fibers than in interstitial intramuscular cells. This was probably due to the presence of myofibrils inside skeletal muscle fibers. On the other hand, prolonged protease treatment reduced signal intensities in nonmuscle cells. We therefore selected intermediate protease digestion conditions, but in keeping with the main objectives of this study, priority was assigned to the detection of hybridization signal in muscle fibers. As a result, although no early IGF1 mRNA response could be detected in nonmuscle cells even under optimal conditions (data not shown), relative signal intensities between different cell types in our muscle in situ hybridization experiments should not be overinterpreted. In addition, the data presented in this study are of a qualitative nature, and attempts to estimate mRNA quantities from labeling intensities would probably be of very little value. On the other hand, the more quantitative Northern blot data of Ishii on mus- cle IGF mRNA (Glazner and Ishii, 1989; Ishii, 1989) suggest that message levels after denervation or paralysis are comparable to those found before the developmental synapse elimination period when muscle IGF1 and IGF2 mRNAs are downregulated. Therefore, the biological impact of the growth factors in inactive muscle may be comparable to that displayed during development, that is, at a time when IGFs are expected to be major regulators of muscle growth and of differentiation (Hall and Sava, 1983; Froesch et al., 1985; Florini et al., 1991).

\section{Early signaling by IGFI in paralyzed skeletal muscle}

Our data indicate that not only IGF1 mRNA but also the corresponding protein is rapidly elevated in denervated or paralyzed muscle. On the other hand, even a quantitative determination of IGF1 protein in muscle may not be sufficient to assess the possible biological impact of the growth factor, as its effective concentration is further affected by the presence of specific IGF-binding proteins (Nissley and Rechler, 1984; Froesch et al., 1985; Baxter and Martin, 1989). Therefore, to determine whether IGF1 may play a signaling role in inactive muscle, we locally applied excess IGF-BP5 or IGF-BP4 to prevent activation of IGF-Rs by IGF1 and IGF2. While the biological functions of IGF-BPs are presently not clear, a 10-fold molar excess of IGF-BP5 or IGF-BP4 over IGFs is sufficient to 

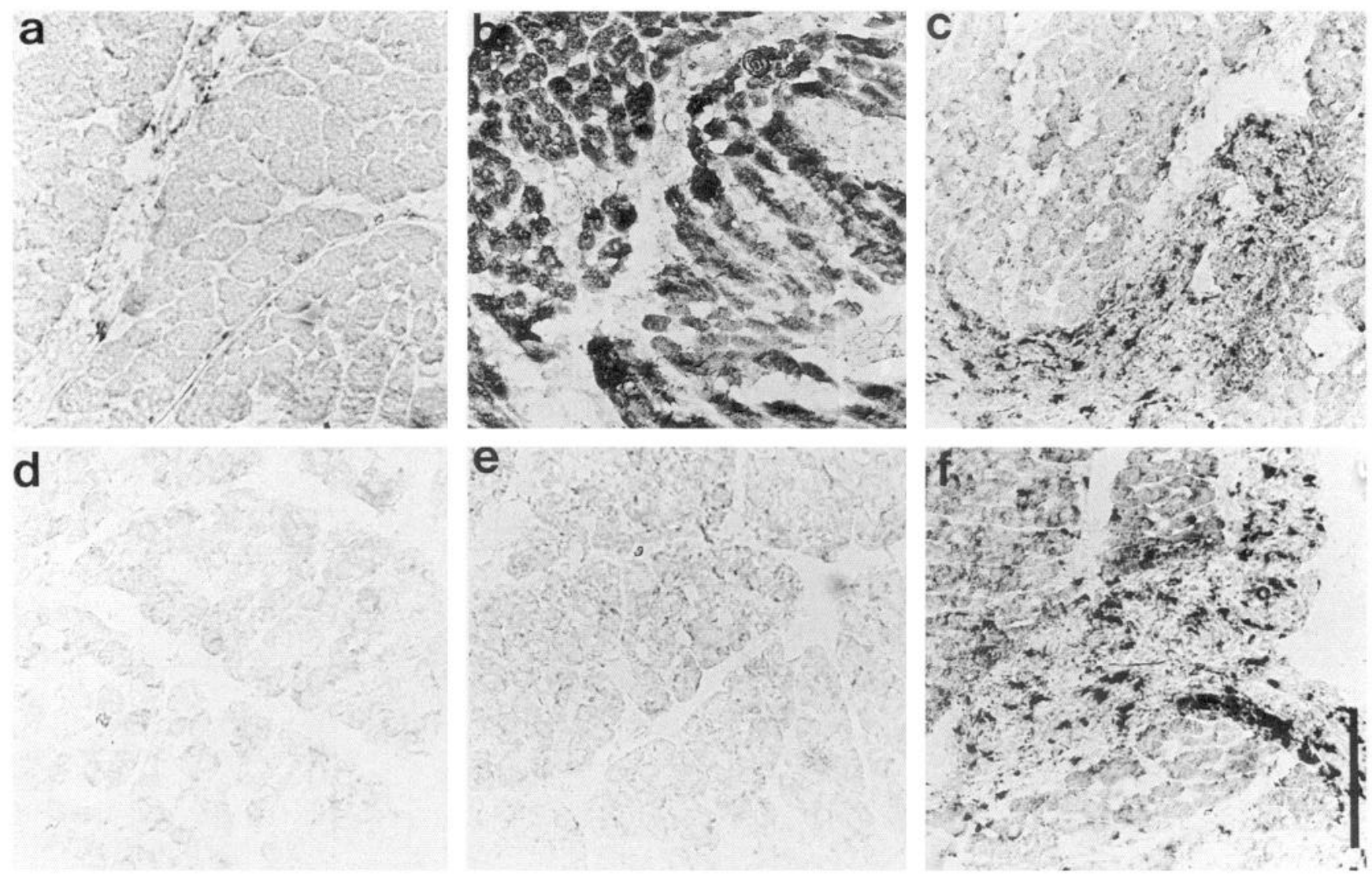

Figure 4. IGF1 and IGF2 mRNA in botulinum toxin-paralyzed 1-month-old rat gluteus muscle. $a-c$, IGF1 mRNA; $d-f$. IGF2 mRNA. $a$ and $d$. contralateral, carrier-exposed muscle, $8 \mathrm{~d}$ after injection; $b$ and $e$, paralyzed muscle, $2 \mathrm{~d}$ after injection; $c$ and $f$, paralyzed muscle, $8 \mathrm{~d}$ after injection. Note that unlike IGF1 mRNA. IGF2 mRNA did not display the rapid elevation in skeletal muscle fibers, and that both messages were detectable in connective tissue cells $8 \mathrm{~d}$ after paralysis (arrowheads in $c$ and $f$ ). Data are from one representative experiment; comparable relative signal intensities were detected in five analogous experiments. Scale bar, $130 \mu \mathrm{m}$.

reduce biological responses to these growth factors in vitro by more than $95 \%$ (Kiefer et al., 1992). The blocking activities of IGF-BP5 and IGF-BP4 are presumably due to their very high affinities for both IGF1 and IGF2. Thus in vitro dissociation constants between the IGFs and these IGF-BPs are 10-100-fold lower than those between IGFs and the IGF1-R (Kiefer et al., 1992). In addition, the binding activities of IGF-BPs are highly specific for IGF1 and IGF2, since the same binding proteins failed to bind to a wide range of growth factors, even when the latter were tested at comparatively high and unphysiological concentrations (Kiefer et al., 1992). For these reasons, IGF-BP5 and IGF-BP4 are useful reagents to suppress specifically the biological activities of IGF1 and IGF2 in vitro, and presumably also in vivo.

We show here that short-term daily applications of IGF-BP5 or delivery of IGF-BP4 to botulinum toxin-treated muscle for $7 \mathrm{~d}$ essentially abolished the interstitial cell proliferation reaction in paralyzed muscle. Therefore, our findings indicate that IGFs are required for the interstitial cell proliferation reaction in paralyzed muscle. When combined with the observation that elevated levels of IGFs are sufficient to promote interstitial cell proliferation in otherwise untreated adult skeletal muscle (Caroni and Grandes, 1990), our findings support the hypothesis that the early production of IGF1 by the inactive muscle fiber is involved in the initiation of the proliferation reaction.

\section{Possible functions of IGFs in inactivated skeletal muscle}

IGFs may be important growth factors in muscle growth and differentiation; in contrast to other growth factors present in muscle during development, IGFs are not only mitogens but also differentiation factors for muscle cells (Florini et al., 1991). IGFs induce differentiation in myogenic cell lines in vitro (Shimizu et al., 1987; Tollefsen et al., 1989) and, interestingly, an early response of myogenic mouse $\mathrm{C} 2$ cells to myotube fusioninducing conditions is the transient elevation of IGFI mRNA and protein (Tollefsen et al., 1989). The response of muscle cell IGFs to differentiation stimuli and the promotion of myogenic differentiation by IGFs have led to the suggestion that IGFs may act in an autocrine manner in muscle cells (Tollefsen et al., 1989; Florini et al., 1991).

The time courses of the IGF1 response in myogenic cells induced to differentiate in vitro (Tollefsen et al., 1989) and in denervated or paralyzed adult muscle fibers in vivo were similar. A very similar time course of rapid induction in about 10-15 $\mathrm{hr}$, followed by peak values at $1-3 \mathrm{~d}$, and by intermediate longterm values has been described in denervated muscle for the AChR $\alpha-, \gamma-$, and $\delta$-subunit mRNAs (Tsay and Schmid, 1990), and for myogenin and MyoD mRNA (Eftimie et al., 1991). Therefore, a set of genes, including that coding for IGF1, may be regulated together in inactive muscle fibers (see also Laufer 


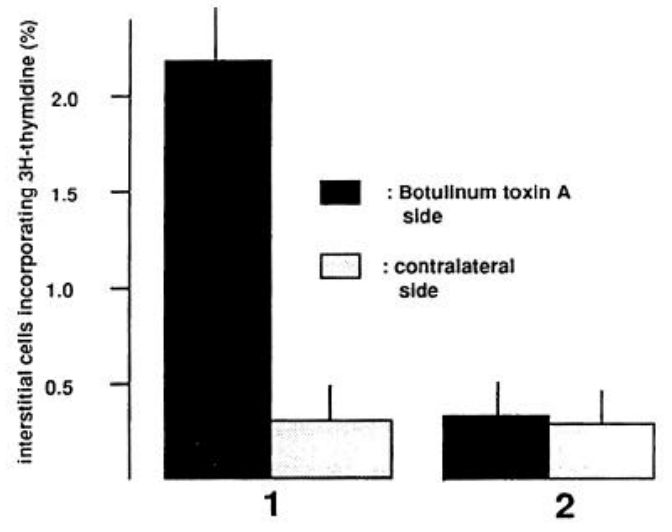

\section{CON}
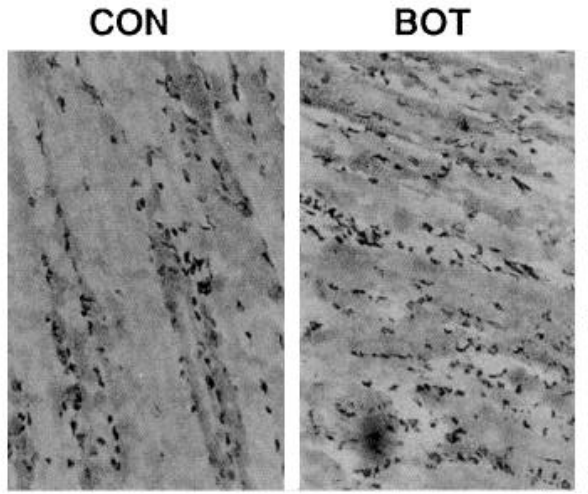

Figure 5. Prevention of the interstitial cell proliferation reaction in paralyzed mouse gluteus muscle in the presence of IGF-BP5 or IGFBP4. Top, Two and one-half days after paralysis. Unilateral subcutaneous injections of $1 \mu \mathrm{g}$ of purified recombinant human IGF-BP5 were applied daily in the vicinity of the original botulinum toxin injection site. The fraction of interstitial cells incorporating ${ }^{3} \mathrm{H}$-thymidine is given as percentage. Data are from four mice each and experimental details were as described in Table 1. 1, Control mice; unilateral local paralysis, no IGF-BP5; 2, IGF-BP5-treated mice. Bottom, Seven days after paralysis. Representative cresyl violet-stained sections from end-platecontaining regions of the muscle are shown. Where indicated, IGF-BP4 was delivered for $7 \mathrm{~d}$ with an osmotic minipump. $C O N$, contralateral nonparalyzed muscle; $B O T$, toxin-paralyzed muscle; $B O T+B P 4$, paralyzed muscle treated with IGF-BP4. Scale bar, $100 \mu \mathrm{m}$.

and Changeux, 1989; Witzemann et al., 1991). However, in contrast to the AChR and to the skeletal muscle-specific transcriptional regulators myogenin and MyoD, IGF1 can transmit information to surrounding cells and to intramuscular nerves.

What cells, besides the muscle fibers, may respond to elevated IGF1 in inactive muscle? In vitro, most cell types are affected by IGFs, including muscle cells, fibroblasts, glia, and neurons (Nissley and Rechler, 1984; Froesch et al., 1985; Rechler and Nissley, 1985; Shemer et al., 1987; Florini et al. 1991). The presence of IGF1-Rs has been demonstrated in many cell types in vitro and in vivo (Nissley and Rechler, 1984; Rechler and Nissley, 1985; Shemer et al., 1987; Werner et al., 1989). We found that IGF1-R mRNA was present in muscle fibers and in intramuscular interstitial cells before and after paralysis (data not shown). In addition, IGF1-R mRNA could be detected in large cell bodies in the ventral horn of the spinal cord, indicating that it is probably present in adult motoneurons in vivo (data not shown; see also Lewis et al., 1994).

Our findings suggest that muscle fiber-derived IGF1 may trigger the early and transient interstitial cell proliferation reaction after paralysis or denervation. Proliferating interstitial cells, in turn, may contribute to the establishment of a favorable local environment for intramuscular nerve growth (Sanes and Couvault, 1985; Gatchalian et al., 1989; Sanes, 1989). The interstitial cell proliferation reaction was more prominent in the vicinity of the inactive $\mathrm{nmj}$; this was described for denervated muscle (Connor and McMahan, 1987; Gatchalian et al., 1989), and it could also be observed in this study in botulinum toxinparalyzed muscle. We detected accumulation of IGF1 immunoreactivity at the neuromuscular junction, but it is not clear whether this very local accumulation may be sufficient to produce the elevated perisynaptic cell proliferation response after muscle inactivation. On the other hand, the recently discovered unique properties of Schwann cells and fibroblasts in the vicinity of the nmj (Weis et al., 1991) and/or the specialized extracellular environment in perisynaptic spaces (Sanes and Couvault, 1985; Couvault and Sanes, 1986; Sanes, 1989) may produce an elevated responsiveness of perisynaptic cells to proliferative stimuli.

Finally, IGF1 may directly initiate reactions in motoneurons leading to intramuscular sprouting. IGFs stimulate neurite outgrowth and branching in vitro; this has been shown for several types of peripheral neurons (Recio-Pinto et al., 1986), including embryonic motoneurons (Caroni and Grandes, 1990). In addition, elevated levels of IGFs in intact adult muscle are sufficient to cause elevated GAP-43 immunoreactivity in intramuscular nerves (Caroni and Grandes, 1990), and elevated GAP-43 mRNA in spinal cord motoneurons (Caroni and Becker, 1992). Therefore, IGF1 in the muscle can affect protein and mRNA levels for a growth-associated protein in the corresponding motoneurons. Whether IGFI affects motoneurons directly or indirectly may be very difficult to test properly, but the mentioned effects of elevated muscle IGF1 on motoneurons and the observation that exogenous IGF1 accumulates at the neuromuscular junction and along motoneuron processes lend support to the hypothesis that diffusible substances, including IGF1, may participate in sprouting. Probably, however, such activities alone are not responsible for the sprouting response. It is likely that additional important factors include cell adhesion molecules, and a convincing relation between intramuscular side branch formation during development and muscle fiber N-CAM levels could recently be documented (Tosney et al., 1986; Dahm and Landmesser, 1988, 1991; Landmesser et al., 1988). Furthermore, changes in ACh receptor levels (Drachman and Pestronk, 1985) and in cell adhesion, extracellular matrix (Sanes, 1989), and extracellular protease molecules (Festoff and Hantai, 1987) have been related to intramuscular nerve sprouting after denervation.

\section{Conclusions}

Our data identify IGFl as a likely initiator of restorative reactions in inactivated muscle. Similar local cell proliferation reactions and nonspecific, local nerve sprouting reactions have been described in other denervated or lesioned systems in the PNS and in the CNS (Purves and Lichtmann, 1985). It will therefore be interesting to determine whether similar growth factors with a broad range of action are elevated in other deafferented target regions. Finally, analogous experiments with IGFBPs, aimed at directly preventing the action of IGF1 in inactive muscle, may reveal whether this growth factor is also required to initiate intramuscular nerve sprouting. 


\section{References}

Baldwin TJ, Theirot JA, Yoshikara CM, Burden SJ (1988) Regulation of the transcript encoding the 43 kilodalton subsynaptic protein during development and after denervation. Development 104:557-564.

Ballotti R, Nielsen FC, Pringle N, Kowelski A, Richardson WD, VanObbergshen E, Gammeltoft S (1987) Insulin-like growth factor I in cultured rat astrocytes: expression of the gene, and receptor tyrosine kinase. EMBO J 6:3633-3639.

Baxter RC, Martin JL (1989) Binding proteins for the insulin-like growth factors: structure, regulation and function. Prog Growth Factor Res 1:49-68.

Beck F, Samani NJ, Peuscow JD, Thorly B, Tregear GW, Coshlan JP (1987) Histochemical localization of IGF-I and -II mRNA in the developing rat embryo. Development 101:175-184.

Bixby JL, Pratt RS, Lilien J, Reichardt LF (1987) Neurite outgrowth on muscle cell surfaces involves extracellular matrix receptors as well as $\mathrm{Ca}^{2+}$-dependent and -independent cell adhesion molecules. Proc Natl Acad Sci USA 84:2555-2559.

Brown MC (1984) Sprouting of motor nerves in adult muscles: a recapitulation of ontogeny. Trends Neurosci 7:10-14.

Brown MC, Holland RL, Hopkins WG, Keynes RK (1980) An assessment of the spread of the signal for terminal sprouting within and between muscles. Brain Res 210:145-151.

Brown MC, Holland RL, Hopkins WG (1981) Motor nerve sprouting. Annu Rev Neurosci 4:17-42.

Caroni P, Becker M (1992) The down-regulation of growth-associated proteins in motoneurons at the onset of synapse elimination is controlled by muscle activity and IGFI. J Neurosci 12:3849-3861.

Caroni P, Grandes P (1990) Nerve sprouting in innervated adult skeletal muscle induced by exposure to elevated levels of insulin-like growth factors. J Cell Biol 110:1307-1317.

Connor EA, McMahan UJ (1987) Cell accumulation in the junctional region of denervated muscle. J Cell Biol 104:109-120.

Couvault J, Sanes JR (1985) Neural cell adhesion molecule (N-CAM) accumulates in denervated and paralyzed skeletal muscle. Proc Natl Acad Sci USA 82:4544-4548.

Couvault J, Sanes JR (1986) Distribution or N-CAM in synaptic and extrasynaptic portions of developing and adult skeletal muscle. J Cell Biol 102:731-739.

Dahm LM, Landmesser LT (1988) The regulation of intramuscular nerve branching during normal development and following activity blockade. Dev Biol 130:621-644.

Dahm LM, Landmesser LT (1991) The regulation of synaptogenesis during normal development and following activity blockade. J Neurosci 11:238-255.

Dull TJ, Gray A, Hayflick JS, Ullrich A (1984) Insulin-like growth factor II precursor gene organization in relation to insulin gene family. Nature 310:777-781.

Eftimie R, Brenner HR, Buonanno A (1991) Myogenin and MyoD join a family of skeletal muscle genes regulated by electrical activity. Proc Natl Acad Sci USA 88:1349-1353.

Festoff BW, Hantai D (1987) Plasminogen activators and inhibitors: roles in muscle and neuromuscular regeneration. Prog Brain Res 71: $423-431$

Florini JR, Ewton DZ, Magri KA (1991) Hormones, growth factors, and myogenic differentiation. Annu Rev Physiol 53:201-216.

Fontaine B, Changeux J-P (1989) Localization of nicotinic acetylcholine receptor $\alpha$-subunit transcripts during myogenesis and motor endplate development in the chick. J Cell Biol 108:1025-1037.

Froehner SC (1989) Expression of RNA transcripts for the postsynaptic $43 \mathrm{kDa}$ protein in innervated and denervated rat skeletal muscle. FEBS Lett 249:229-233.

Froesch ER, Schmid C, Schwender J, Zapf J (1985) Actions of insulinlike growth factors. Annu Rev Physiol 47:443-467.

Gatchalian CL, Schachner M, Sanes JR (1989) Fibroblasts that proliferate near denervated synaptic sites in skeletal muscle synthesize the adhesive molecules tenascin (J1), N-CAM, fibronectin, and a heparin sulfate proteoglycan. J Cell Biol 108:1873-1890.

Glazner GW, Ishii DN (1989) Relationship of insulin-like growth factor I mRNA content to synaptogenesis in rat skeletal muscle. Soc Neurosci Abstr 15:1353.

Goldman D, Brenner HR, Heinemann S (1988) Acetylcholine receptor $\alpha, \beta, \gamma$, and $\delta$-subunit mRNA levels are regulated by muscle activity. Neuron 1:329-333.
Hall K, Sava VR (1983) Growth and somatomedins. In: Vitamins and hormones, Vol 40. New York: Academic.

Han VK, D'Ercole AJ, Lund PK (1987) Cellular localization of somatomedin (insulin-like growth factor) messenger RNA in the human fetus. Science 236:193-197.

Henderson CE, Huchet M, Changeux J-P (1983) Denervation increases a neurite-promoting activity in cxtracts of skeletal muscle. Nature 302:609-611.

Holland RL, Brown MC (1981) Nerve growth in botulinum toxin poisoned muscles. Neuroscience 6:1167-1179.

Ishii DN (1989) Relationship of insulin-like growth factor II gene expression in muscle to synaptogenesis. Proc Natl Acad Sci USA 86: 2898-2902.

Kao I, Drachman DB, Price DL (1976) Botulinum toxin: mechanism of presynaptic blockade. Science 193:1256-1258.

Kiefer MC, Schmid C, Waldvogel M, Schlapfer I, Futo E, Masiarz FR, Green K, Barr PJ, Zapf J (1992) Characterization of recombinant human insulin-like growth factor binding proteins 4,5 and 6 produced in yeast. J Biol Chem 267:12692-12699.

Kuffier DP (1989) Regeneration of muscle axons in the frog is directed by diffusible factors from dencrvated muscle. J Comp Neurol 281: 416-425.

Kuoner DJ, Smith GL (1980) Inhibition of biological action of multiplication-stimulating activity by binding to its carrier protein. Proc Natl Acad Sci USA 77:7252-7256.

Landmesser LT, Dahm L, Schultz K, Rutishauser U (1988) Distinct roles for adhesion molecules during innervation of embryonic chick muscle. Dev Biol 130:645-670.

Laufer L, Changeux J-P (1989) Activity-dependent regulation of gene expression in muscle and neuronal cells. Mol Neurobiol 3:1-53.

Lewis ME, Vaught JL, Neff N, Grebow PE, Callison KV, Yu E, Baldino FJr (1994) The potential of IGF-1 as a therapeutic for the treatment of neuromuscular disorders. Ann NY Acad Sci, in press.

Murray NA, Robbins N (1982) Cell proliferation in denervated muscle: time course, distribution, and relation to disuse. Neuroscience 7:1817-1822.

Nissley SP, Rechler MM (1984) Insulin-like growth factors: biosynthesis, receptors, and carrier proteins. In: Hormonal proteins and peptides, Vol 12 (Li CH, ed), pp 127-203. New York: Academic.

Pestronk A, Drachman DB (1985) Motor nerve terminal outgrowth and acetylcholine receptors: inhibition of terminal outgrowth by $\alpha$-bungarotoxin and anti-acetylcholine receptor antibody. J Neurosci 5:751-758.

Purves D, Lichtmann JW (1985) Principles of neural development, pp 179-228, 301-317. Sunderland, MA: Sinauer.

Rechler MM, Nissley SP (1985) The nature and the regulation of the receptors for insulin-like growth factors. Annu Rev Physiol 47:425442.

Recio-Pinto E, Rechler MM, Ishii DN (1986) Effects of insulin, insulin-like growth factor II, and nerve growth factor on neurite formation and survival in cultured sympathetic and sensory neurons. J Neurosci 6:1211-1219.

Rieger F, Grumet M, Edelman GM (1985) N-CAM at the vertebrate neuromuscular junction. J Cell Biol 101:285-293.

Rinderknecht E, Humbel RE (1976) Polypeptides with nonsuppressible insulin-like and cell-growth promoting activities in human serum: isolation, chemical characterization, and some biological properties of forms I and II. Proc Natl Acad Sci USA 73:2365-2369.

Salpeter MM (1987) The vertebrate neuromuscular junction. New York: Liss.

Sanes JR (1989) Extracellular matrix molecules that influence neuronal development. Annu Rev Neurosci 12:491-516.

Sancs JR, Couvault J (1985) Axon guidancc during reinnervation of skeletal muscle. Trends Neurosci 8:523-528.

Sanes JR, Schachner M, Couvault J (1986) Expression of several adhesive macromolecules (N-CAM, L1, tenascin(J1), NILE, uvomorulin, laminin, fibronectin, and a heparin sulfate proteoglycan) in embryonic, adult and denervated adult skeletal muscle. J Cell Biol 102:420-431.

Shemer J, Raizado MK, Masters BA, Ota A, LeRoith D (1987) IGF-I receptors in neuronal and glial cells: characterization and biological effects in primary culture. $\mathrm{J}$ Biol Chem 262:7693-7699.

Shimizu M, Webster C, Morgan DO, Roth RA (1986) Insulin and insulin-like growth factor receptors and responses in cultured human muscle cells. Am J Physiol 251:611-615. 
Slack JR, Pockett S (1981) Terminal sprouting of motoneurones is a local response to a local stimulus. Brain Res 217:368-374.

Thesleff S (1989) Botulinal neurotoxins as tools in studies of synaptic mechanisms. Q J Exp Physiol 74:1003-1017.

Tollefsen SE, Lagara R, McCusher RH, Clemmons DR, Rotwein P (1989) Insulin-like growth factors in muscle development: expression of IGF-I, the IGF-I receptor, and an IGF binding protein during myoblast differentiation. J Biol Chem 264:13810-13817.

Tosney K, Watanabe M, Landmesser LT, Rutishauser U (1986) The distribution of N-CAM in the chick hindlimb during axon outgrowth and synaptogenesis. Dev Biol 114:437-452.

Tsay H-J, Schmid J (1990) Skeletal muscle denervation activates acetylcholine receptor genes. J Cell Biol 108:1523-1526.

Weis J, Fine SM, David C, Savarirayan S, Sanes JR (1991) Integration site-dependent expression of a transgene reveals specialized features of cells associated with neuromuscular junctions. J Cell Biol 113 : $1385-1397$.

Werner H, Woloschak M, Adamo M, Shen-Orr Z, Roberts CT, LeRoith D (1989) Developmental regulation of the rat insulin-like growth factor I receptor gene. Proc Natl Acad Sci USA 86:7451-7455.

Witzemann V, Brenner HR, Sakmann B (1991) Neural factors regulate AChR subunit mRNAs at the rat neuromuscular synapses. J Cell Biol 114:125-141.

Yang YW-H, Wang J-F, Orlowski CC, Nissley SP, Rechler MM (1989) Structure, specificity and regulation of the insulin-like growth factor binding proteins in adult rat serum. Endocrinology 125:1540-1552.

Zapf J, Schoenle E, Jagars G, Sand I, Grunwald J, Froesch ER (1979) Inhibition of the action of non-suppressible insulin-like activity on isolated rat fat cells by binding to its carrier protein. J Clin Invest 63: 1077-1084. 